\title{
Discrete dynamic bell type instrument of combined work principle for the calibration of gas meters
}

\author{
Mazur V', Rak A, and Shchupak I \\ SE "Ukrmetrteststandard”, Kiev, Metrologichna 4 str., Ukraine
}

\begin{abstract}
Résumé. L'article est destiné pour expliquer une nouvelle approche de création des installations de sondage combiné pour l'étalonnage des compteurs à gaz. Les auteurs ont analysé les sources principales des erreurs des constructions classiques des gazomètres, en plus ils ont développé les solutions pratiques pour minimiser l'incertitude de mesure. L'utilisation de servo pour le pilotage de mouvement de sondage minimise la durée de processus de transfert aussi bien que donne la possibilité d'obtenir l'utilisation optimale du volume interne de l'installation pendant la reproduction du volume et le débit de gaz volumétriques. Les résultats de la recherche de stabilité de pression dans l'espace sous sondage sont mentionnés dans l'article pour prover la faisabilité de la mise en œuvre technique.
\end{abstract}

\section{Introduction}

In difficult conditions Ukraine has taken its way for the state building on the base of European values, creation of prerequisites for development of society, which focused on particular citizen, increasing his spiritual and material wellness.

Among strategic tasks of Ukrainian National Renaissance undoubtedly there is a task of orientation of goods and services to European and world market, providing necessary conditions for effective and selfsufficient functioning of National economy as a part of world economic.

This task can be solved on the background of three components:

- developed and focused on the demands of state economy and defense National metrology system which is able to provide measurements traceability and more important - to provide acknowledgement of obtained measurements results in the world;

- $\quad$ adapted to market economy system of products and services certification as a tool of consumer's protection by safety, reliability indexes etc.;

- $\quad$ harmonized with International norms standardization system.

These priorities require significant improvement of measuring abilities as well as further development of theoretical metrology particularly in the terms of materials and energy accounting.

So national metrological infrastructure is an important element of economic progress of developing countries. Absence of acknowledged on International level and traceable tests and measurements results put a country into dependence toward the developed states.
Our institution (SE "Ukrmetrteststandard") is signatory of International agreement on inter-acknowledgement of National standards and calibration certificates CIPM MRA which covers 15 national standards. Considering the unpredictable situation with natural gas supply from Russia our organization takes the efforts on improvement of natural gas volume and volume flow standards over last year. Enhancements are concerned the following:

- improvement of standard on the base of bell-type prover with consideration of hidden factors affected the accuracy of storage and reproduction of natural gas volume and volume flow;

- $\quad$ using the artificial gas substance with physical and physical-chemical properties of natural gas as measuring medium;

- implementation of natural gas accounting on the base of energy characteristics.

Of course realization of mentioned above directions takes certain time. Currently the first direction is worked out.

\section{Current stage and problems of metrological assurance of natural gas volume and volume flow measurements}

Today Ukraine is forced to import primary energy sources. First of all it is concerned the natural gas. This is determined by the long list of problems of internal energy consumption and energy saving and now it is one of the greatest threat to national security and sovereignty and at

${ }^{1}$ MazurV Vmazuritto@gmail.com 
the same time it is the key obstacle on the way to stable economical development. Among the main problems we could specify the following:

- ineffectiveness energy consumption in the country that means ineffective methods of energy conversion and convey in municipal and household section (49\% of total energy consumption), outdated production technologies (in particular from $22 \%$ of natural gas consumable by Ukrainian industry $14 \%$ are used by metallurgy) [1].

- absence of trends for natural gas accounting enhancement by means of modern technologies (natural gas accounting on gas measuring stations currently is still carried out by differential pressure method that can't provide accuracy higher then 1,5\% [2]) when most countries in the world use high precision ultrasonic and turbine flowmeters for natural gas flow and quantity accounting etc.;

- absence of relevant metrological assurance and instrument base (currently there is any calibration rig for pressure less then 1,6 $\mathrm{MPa}$ with natural gas as working medium in Ukraine) [3].

- absence or bureaucracy and corruption obstacles in implementation of global state programs of energy savings on the background of total deterioration of existing housing.

According to official government information Ukraine gains the lead by level of energy consumption to one dollar of gross domestic product. At the same time national economy providing by energy sources of internal mining is less then $60 \%$.

\section{Standard bell-type provers and the main error sources in their operation}

Technical means for reproducing of volume and volume flow units by their operational features first of all are designed for providing of unit size transferring to measuring instrument that directly used for measurements. So by metrological purpose priority here-in-after such technical solutions will be called "standard prover" (SP).

Standard bell-type provers are well-known metrological instrument for reproducing of gas volume flow unit. For the first time a such prover was used about 100 years ago [4]. In their design few operational principles can be used, in particular:

- portion-static (equipment-under-the test readings are taken off when sensitive element is immovable);

- continuously-cycled (measuring medium flow is reproduced in portions with disturbance when coupling);
- discrete dynamic (the single discrete doze is separated from gas flow and its size is measured by equipmentunder-the test in dynamic mode)

Key element of bell-type prover is bell (cylindrical measure without one of two bases) immersed by open end into the tank with packing liquid.

Operational principle of such prover is based on immersing of bell (1) under its own weight balanced by counterweight (5) into the tank filled by low steamy packing liquid (2), hereupon the gas flow is appeared in the pipe (3) connecting EUT (6) with volume under bell (see fig.1). Control of displacement size can be fulfilled by different methods (for example non-contact optic registers or slots).

Different well-known technical means (such as Archimedean spiral or profiled pulley (4)) are used for buoyancy compensation to provide pressure stability under the bell which is the main condition for providing of flow stability.

Volumetric flow realized by bell-type provers taking into account heat exchanging dynamic processes at first approximation can be presented on the base of mass conversion principle:

$$
0=\frac{\partial}{\partial t} \int_{V} \rho d V+\int_{S} \rho \bar{v} \cdot d \vec{S}
$$

where: $\rho$ is density of measuring medium; $\frac{\partial}{\partial t}$ is partial time derivative; $V$ is total control volume which is sum of volumes $V_{a}, V_{b}$ and $V_{c}$ (see fig.1); $S$ is the area enclosing control volume under the bell. The quantity $\bar{v}$ is velocity vector of the fluid and $d \vec{S}$ is the vectorial control surface element of area with direction taken outward and normal to the surface.

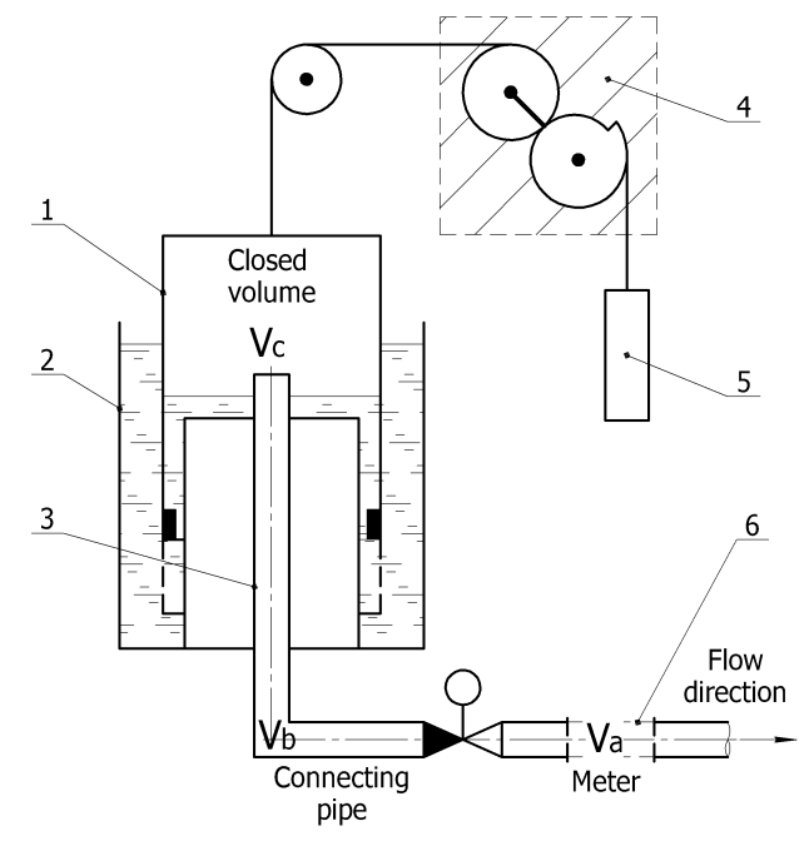

Figure 1. Standard bell-type prover principle scheme 
1 - bell; 2 - tank with packing liquid; 3 - connecting pipe; 4 - system of buoyancy compensation; 5 - counterweight for bell weight compensation; 6 - measuring section for meter.

From ratio (1) after some conversions it is possible to obtain the equation which generally can be used as main measuring equation for standard bell-type provers:

$$
Q_{V}=\frac{h \cdot S}{\Delta t}+\frac{\Delta \rho \cdot V_{C}}{\rho \cdot \Delta t}+Q_{E}
$$

where: $Q_{V}$ is volumetric flow, $\left[\mathrm{m}^{3} / \mathrm{sec}\right] ; h$ is the length of the vertical displacement of the bell, [m]; $S$ is bell crosssection area, $\left[\mathrm{m}^{2}\right] ; V_{C}$, the residual gas volume under the bell, $\left[\mathrm{m}^{3}\right] ; \Delta t$, the time interval of measuring cycle, $[\mathrm{sec}] ; \rho$ is the density of discharged gas, $\left[\mathrm{kg} / \mathrm{m}^{3}\right] ; \Delta \rho$, the change of gas density during the measuring cycle, $\left[\mathrm{kg} / \mathrm{m}^{3}\right] ; Q_{E}-$ additional volumetric flow due to imperfection of packing liquid level control system, bell heat expansions etc., $\left[\mathrm{m}^{3} / \mathrm{sec}\right]$;

The advantage of such form of main equation is summand $\frac{\Delta \rho \cdot V_{C}}{\rho \cdot \Delta t}$ allowing to take into account dynamic of change of measuring medium parameters.

Significant error sources that should be considered with bell-type prover working are bell volume determination error, error connected with pressure instability during measuring cycle due to effects of mechanical and hydromechanical resistance forces, inaccuracy of bell buoyancy compensation etc. Also important could be error sources from ambient temperature changes leading to changes in geometric bell dimensions and error due to packing liquid level change.

Low performance in portion-static mode and long exposure for stabilization of heat exchanging processes under the bell volume due to bell lifting implemented by feeding the compressed gas under the bell, could be considered as shortcomings of "classic" bell-type provers.

Standard bell-type prover uncertainty budget is given in Table 1 [5].

Table 1. Bell prover uncertainty budget

\begin{tabular}{lc}
\hline \multicolumn{1}{c}{ Uncertainty source } & $\begin{array}{c}\text { Relative standard } \\
\text { uncertainty, \% }\end{array}$ \\
\hline Bell measure & 0,015 \\
Air density & 0,030 \\
Time measurement & 0,040 \\
Residual volume in system & 0,01 \\
Non-considered volumes & 0,01 \\
\hline
\end{tabular}

In such bell-type provers the working medium is an air. But implemented operational principle allows to use any other gas or gas mixture including natural gas as working medium $[6,7]$.

As mentioned above the main shortcoming of portionstatic standard bell-type provers is impossibility to exclude unstable operational mode i.e. obtaining by bell the velocity $i \quad v_{i}=$ const is reached under condition $\sum_{j=1}^{n} \bar{F}_{j} \rightarrow 0[8]$ within some time interval $\Delta \tau$. Thus to minimize the effect of this factor to metrological characteristics of SP it is necessary to increase the duration of measuring cycle and hence the bell should have rather large volume that in turn entails increasing of prover's costs and has negative effect on gas temperature stability under the bell. For instance, to reach the flow rate of $0,28 \mathrm{~m}^{3} / \mathrm{s}\left(1000 \mathrm{~m}^{3} / \mathrm{h}\right)$ it is necessary to use bell measure of $50 \mathrm{~m}^{3}[9]$.

\section{Bell-type prover of combined operational principle}

Analysis of volume and volume flow unit size realization methods shows, that measurements accuracy strongly depend on staff qualification. Thus for performing up-todate complicated researches it is important not only to provide specific conditions but also to follow strict and consistent reproduction of process operations. Thereby automation of measurement process is one of necessary requirements for obtaining of high accuracy and repeatability of measurement results.

Significant enhancement of such type provers can be reached by implementation of innovative solutions only, because further modernization of classical design now is almost impossible.

Combined standard bell-type prover developed by SE "Ukrmetrteststandard" specialists on the base of classic bell-type prover could be an example of innovative approaches in creation of such type measuring standards. Up-to-date solutions and new technical ideas were used to compensate main error sources inherent for this type provers.

Technical assignment for prover's upgrade supposed increasing accuracy of flow realization and enlarging its dynamic range with simultaneous acceleration of prover operation. Patented method of bell movement control was used to reach these purposes. Such an approach allowed to create the combination of bell-type and piston-type prover (fig.2) and to reduce significantly the duration of transient interval. 


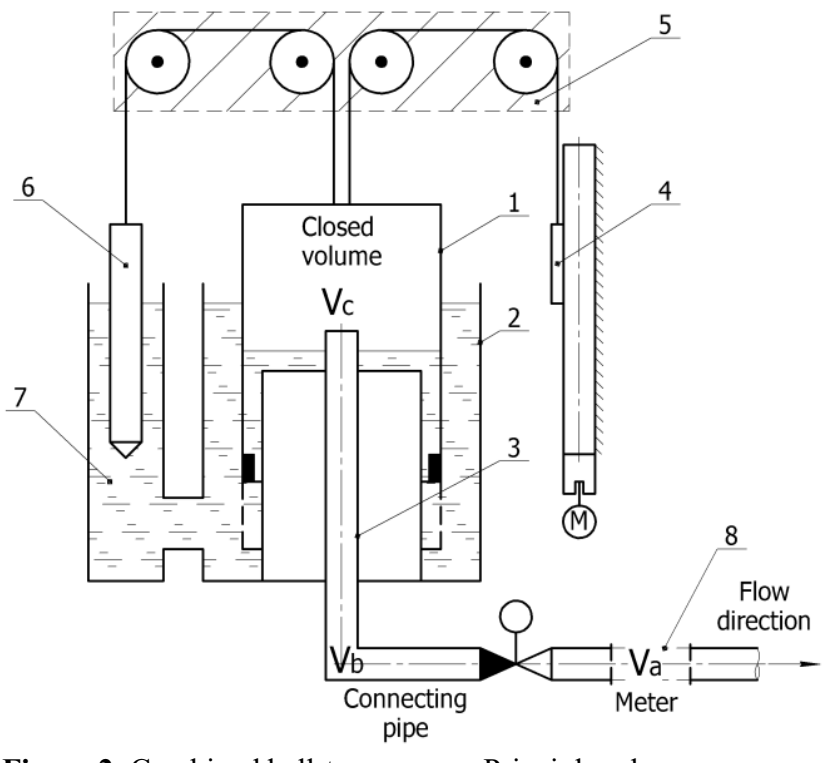

Figure 2. Combined bell-type prover. Principle scheme

1 - bell; 2 - tank with packing liquid; 3 - connecting pipe; 4 - precision servo drive; 5 - set of guiding pulleys; 6 calibrated counterweight; 7 - additional tank; 8 measuring section for EUT.

Operation principle of such combined prover unlike the mentioned above classic one bell is the movement parameters could be assigned and controlled by servodrive connected to bell by mean of flexible metal tape. Prover's operational principle is based on determination of time interval that is needed for bell to discharge specific volume under certain temperature and pressure of measuring media. Hence for measuring interval $\Delta t=t_{2}-t_{1}$ considering ratio (1) the main measuring equation for polytrophic process can be presented as following [10]:

$$
\begin{aligned}
Q_{V}=\left(\frac{h \cdot S}{\Delta t}\right. & \left.+Q_{E}\right) \cdot\left(1+\frac{\bar{p}_{12}}{P_{a}}+\frac{1}{\gamma}\left[\frac{p_{2}-\bar{p}_{12}}{P_{a}}+\right.\right. \\
& \left.\left.+\frac{p_{2}-p_{1}}{P_{a}} \cdot \frac{V_{C} \cdot \Delta t}{h \cdot S}\right]\right)
\end{aligned}
$$

where: $Q_{V}$ is volumetric flow, $\left[\mathrm{m}^{3} / \mathrm{sec}\right] ; h$ is the length of the vertical displacement of the bell, $[\mathrm{m}] ; S$ is bell crosssection area, $\left[\mathrm{m}^{2}\right] ; V_{C}$, the residual gas volume under the bell, $\left[\mathrm{m}^{3}\right] ; \Delta t$, the time interval of measuring cycle, [sec]; $Q_{E}$ - additional volumetric flow due to imperfection of packing liquid level control system, bell heat expansions etc., $\left[\mathrm{m}^{3} / \mathrm{sec}\right] ; \bar{p}_{12}$ is averaged absolute gas pressure under the bell during measuring cycle, $[\mathrm{Pa}] ; \gamma$ - adiabatic index; $P_{a}$ - gauge pressure, $[\mathrm{Pa}] ; p_{1}$ and $p_{2}-$ pressure under the bell at the start and end of measuring cycle respectively, [Pa].

In fact, equation (3) is slightly modified of piston prover measuring equation and it gives the opportunity for using of certain mathematical apparatus for researches of combined standard prover.

In addition to mentioned above the innovative solutions were implemented in combined bell-type prover (fig.3):

- bell balance is reached by mean of resultant forces minimization in particular bell weight, counterweight and servo drive's force. Hence pressure under the bell is quasi constant quantity and has no effect on measure moving parameters in any mode. This gives significant increasing of accuracy of flow measurements for control gas volumes and enlarges upper and lower ranges of gas flow realization;

- increasing of prover measurement accuracy is reached by using servo drive equipped with vector control system, that provides setting and keeping necessary velocity of bell sinking by specific algorithm independently on changes of hydro-dynamical resistance forces. And hence buoyancy compensation is not powerful factor for obtaining stable pressure and flow under the bell and doesn't effect to general measurement uncertainty.

- due to feeling of the space under the bell with gas by the mechanical bell lifting without any source of compressed air the working medium temperature changing before measuring cycle seeks to zero. That's why stabilization interval of heat exchange processes under the bell is significantly reduced.

- compensation mass is the calibrated vertical cylinder immersed into the supplementary compensational tank, that hydraulically connected to main tank (communicative vessels). Counterweight is mechanically connected with bell. Due to the fact that in any conventional cross-section area of counterweight cylinder is equal to area of bell cross section ring, and bell and counterweight move in antiphase, the constant level of packing liquid is obtained for any dynamic operational modes.

- the standard prover includes mechanical system consisting of precision guiding columns and linear nodes of special design. This system provides linearity, smoothness and repeatability of bell vertical movement during its sinking. This guarantees stability of realized flow. Additional advantage of such system is possibility of independent vertical selfsetting of guiding columns.

- from mentioned above uncertainty budget structure it is clear that most significant uncertainty source is measurements of bell geometrical dimensions. For this purpose, 3D map of bell surface was created with FARO ${ }^{\circledR}$ Laser Tracker Vantage system. This 3D map has been carefully analyzed and divide for $n$ horizontal belts for precision consideration of true meaning of bell cross section area [11];

- using high precision optical system made by Renishaw with resolution of 1 micron for measurement of bell displacement allowed to create the standard prover that is able to reproduce any control volume in declared range. 


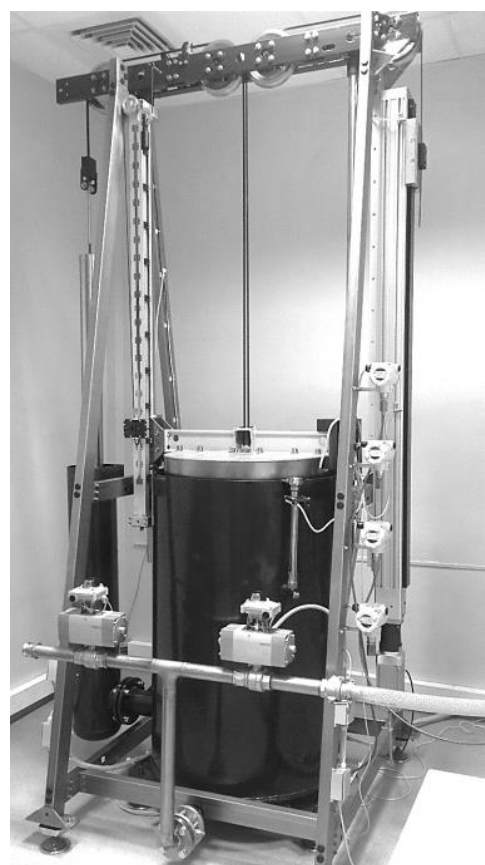

Figure 3. Combined bell-type prover. General view

\section{First research results}

Pressure stability under the bell during the measurement cycle is one of the main factors for obtaining high metrological characteristics of bell-type provers. Investigated combined prover's feature is the servodrive, that used to control of bell velocity. The effectiveness indicator of such a technical solution is the pressure stability under bell space for any dynamic operating mode.

Pressure stability contribution to prover overall error can be estimated by mathematical modeling of gas volumes differences (volume discharged by bell and volume supplied to EUT). For this purpose, following expression can be used [8]:

$$
\delta_{P}=\int_{0}^{h}\left(\frac{\Delta P}{P(d h / d t)}\right) d h
$$

where: $\Delta P$ is absolute pressure change under the bell during discharge of control volume; $h$ is the length of the vertical displacement of the bell; $P(d h / d t)$ - pressure change under the bell law as function of bell movement velocity.

Pressure meanings registered during measuring cycle for volume flowrates of $6,5 \mathrm{~m}^{3} / \mathrm{h}, 10 \mathrm{~m}^{3} / \mathrm{h}, 16 \mathrm{~m}^{3} / \mathrm{h}$, $25 \mathrm{~m}^{3} / \mathrm{h}, 40 \mathrm{~m}^{3} / \mathrm{h}$ and $65 \mathrm{~m}^{3} / \mathrm{h}$ has been chosen for analysis. Five independent observations of pressure difference meanings $\Delta P$ has been made at every flowrate within measuring cycle. Some obtained results are shown on fig. 4-5. Additional error from pressure instability under the bell can be estimated by algorithm (3) (see fig.6).

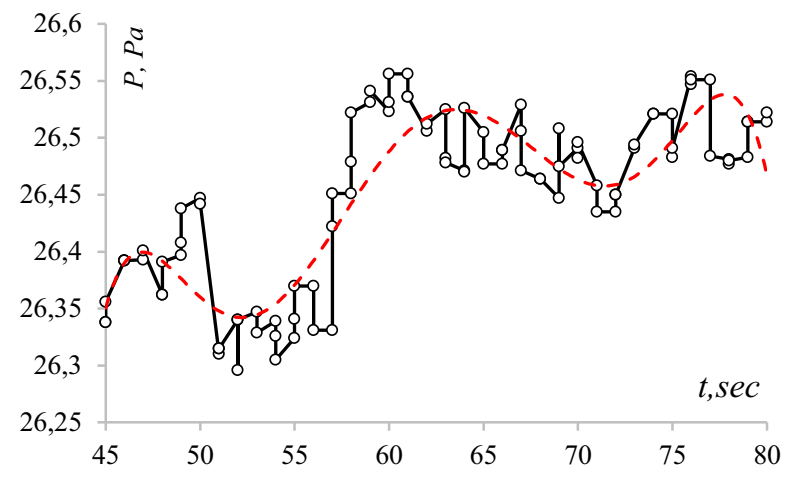

Figure 4. Pressure dependence under the bell $P(v)$ and its approximation at $Q=10 \mathrm{~m}^{3} / \mathrm{h}, \bar{v}=7,511 \cdot 10^{-3} \mathrm{~m} / \mathrm{sec}$

By investigation results the following conclusions has been made:

- pressure difference under the bell looks quasi monotonous during measuring cycle and increases with increasing of volumetric flow rate;

- bell movement control using allows to reach quasi stable pressure under the bell during whole measuring cycle in wide range of volumetric flow rate;

- additional error $\delta_{\Delta \mathrm{P}}$ is in non-linear dependence on volumetric flow rate and can be $0,015 \%$;

- optimal algorithm of servodrive control can be developed on the base of pressure distribution analysis at different flow rates;

- method of bell movement control under condition of stable level of packing liquid in tanks allows to reach stable pressure at large flowrates even without buoyancy compensation system. This simplifies prover design and at the same time improves its metrological characteristics.

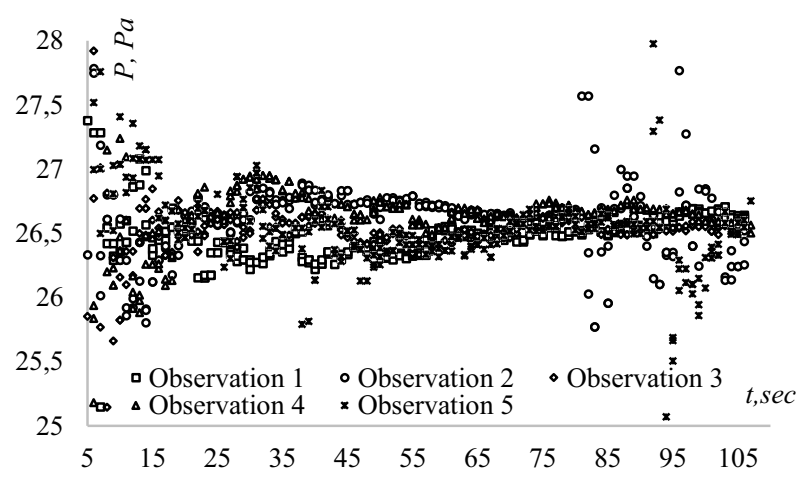

Figure 5. Pressure distribution for five independent observations at volumetric flowrate $Q=10 \mathrm{~m}^{3} / \mathrm{h}$ 


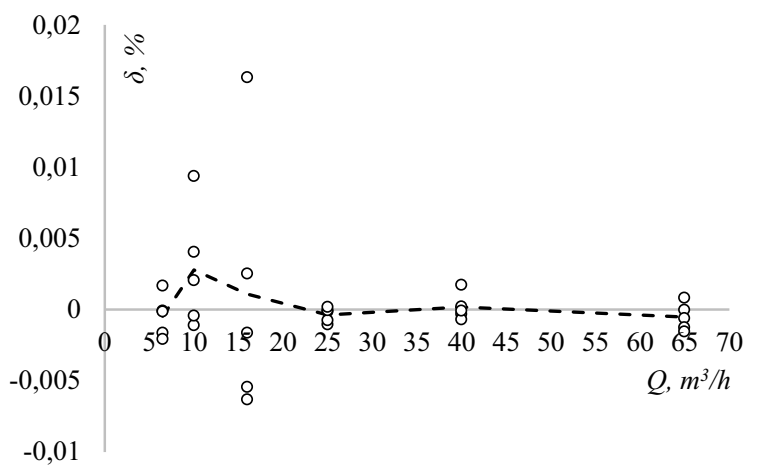

Figure 6. Additional error $\delta_{\triangle \mathrm{P}}$ as function of volumetric flowrate $Q$

\section{References}

1. The energy intensity of GDP (2012), http://uk.wikipedia.org/wiki. (In Ukrainian).

2. Власюк Я. М., Чуприн М. І., Власюк Л.Я., Кониепиія єдиної системи обліку природного газу в Украӥні (Оптимізачія впровадження промислових лічильників різних методів вимірювання) //Методи та прилади контролю якості, (2007). - № 18.- С.

3. Ю.В. Кузьменко, В.В. Онушко, А.М. Рак, І.В. Щупак «Щодо повірки витратомірів-лічильників на природному газі», Украӥнський метрологічний журнал, №4, (2014 р.), стор. 58-60.

4. Pamp H. Standarts for the calibration of gas flowmeters / H. Pamp, P Mahr// Bull Organis. Int. Metrolog. Leg. - (1987). - №107. - P.3 - 20.

5. Benkova M., Makovnik S., Mikulecky I., Zamecnik V. Bell Prover - Calibration and Monitoring of Time Stability. MAPAN - Journal of Metrology Society of India, Vol. 26, No. 3, (2011); pp. 165-171.

6. Пат. 33463 А Україна, МПК 6 G01F25/00. Дзвонова витратовимірювальна установка для калібрування $i$ повірки витратомірів та лічильників газу / Бродин Ю.І.; Заявник і патентовласник Івано-Франківський держ. техн. ун-т нафти і газу. - № 99021060; заявл. 23.02.9; опубл. (15.02.01), Бюл. №1. - 3 с.

7. Бродин Ю.І. Дводзвонова установка відтворення та вимірювання об'єму газу для повірки лічильників газу: автореф. дис. на здобуття наук. ступеня канд. техн. наук: спец. 05.11.01 «Прилади та методи вимірювання механічних величин»/ Ю.І. Бродин. - Львів, (2002). - 19 с.

\section{Conclusion}

Using of proposed technical solution is perspective approach in the sphere of bell-type prover development. It allows significantly increase the accuracy of volumetric flow realization and to improve the process of volumes registration when calibrating volume and volumetric flow measuring instruments. At the same time this solution demands following deep researches in particular of heat exchange processes under the bell during transient interval for further increasing of calibration reliability.

8. Рак А.М, Коробко І.В., д.т.н., доц., Дослідження стабільності тиску в установці дзвонового типу з керованим рухом мірника // Вісник НТУУ «КПІ». Серія машинобудування - (2015). - №1 (73) - С. 107-112.

9. ГСОЕИ. Счётчики газа. Методы и средства поверки: ГОСТ 8.324-78 - [Введен с 1976-01-01]. - М.: Изд. стандартов, (1979). - 13с.

10. Kutin J, Bobovnik G and Bajsic I (2011) Dynamic effects in a clearance-sealed piston prover for gas flow measurements Metrologia 48 123-32.

11. Ю.В. Кузьменко, А.Н. Самойленко «Градуировка колокола установок для поверки счётчиков текучей средьл», Украӥнський метрологічний журнал, №1, (2015 р.), стор. 49-54. 